\title{
Vold og politikk i Iran
}

Finnes det ideologisk belegg for en voldelig orientert bevegelse i Iran?

Yadollah Shahibzadeh er idéhistoriker og tok doktorgraden på den iranske reformbevegelsens ideologiske rotter. 
TEKST: Yadollah Shahibzadeh

DA MAHMUd AHMADINEJAD kom til andre runde av presidentvalget sammen med Hashemi Rafsanjani i sommer, advarte reformvennlige krefter om faren for et fascistisk regime dersom Ahmadinejad skulle vinne valget. Var dette en overdrivelse for å skaffe flere stemmer til Rafsanjani, eller finnes det virkelig en fascistisk bevegelse i Iran?

Frykten for at politisk vold skal gjenoppstå er ikke grunnløs. Ahmadinejads største ideal er gjenreising av Iran som et islamistisk og revolusjonært land slik det var på ı980-tallet. Iran på 8o-tallet var dominert av krig, terrorisme, henrettelser, tortur og borgerkrig. Noen uker etter valget av Ahmadinejad som president offentliggjorde Teheran-seksjonen av Ansar-e Hezbollah en erklæring som truet med voldelig oppgjør med alle motstandere av den islamske staten. ${ }^{\mathrm{I}}$ Ahmadinejads valg av to av ministere, Mohseni Ezhei som etterretnings- og informasjonsminister og Purmohamadi som innenriksminister, forsterket frykten for en ny bølge av politisk vold, siden begge ministere anklages av reformvennlige krefter for å ha spilt en rolle i drap på politiske aktivister og intellektuelle på I990-tallet.

Midt under Ahmadinejads maktovertakelse viser det seg flere symptomer på at en ny runde med vold er i emning i landet: opprør i den sørvestlige provinsen Kuzestan i vår, og i Kurdistan i sommer, flere eksplosjoner i byen Ahvaz og en i Teheran før presidentvalget, den radikale postislamisten og politiske aktivisten Akbar Ganjis anklage mot Ali Khamenei om at han er en illegitim og forbrytersk hersker, drapet på dommeren som bestemte Ganjis fengselstraff, og konflikt med vestlige land med USA i spissen rundt Irans utvikling av kjernefysisk teknologi. Muligheten for at USA går til krig og en ny totalitær politikk kan være kilder til den nye voldsbølgen. Finnes det en dominerende ideologi i Iran $i$ dag som rettferdiggjør vold innenfor landets grenser og krig med utenlandske makter? Spørsmålet blir klarere hvis vi formulerer det slik: Hvordan oppfatter den iranske politiske og religiøse eliten bruk av vold?

\section{Et tilbakeblikk}

Ifølge Emad-edin Baghi er summen av politiske drap, henrettelser og folk som døde mellom begynnelsen av i960 og den revolusjonære maktovertagelsen i I979 3164 personer. $^{2}$ Mange flere ble drept i borgerkrig og henrettet $i$ forskjellige deler av Iran i løpet av I980-tallet i det postrevolusjonære politiske systemet. Den iranske 


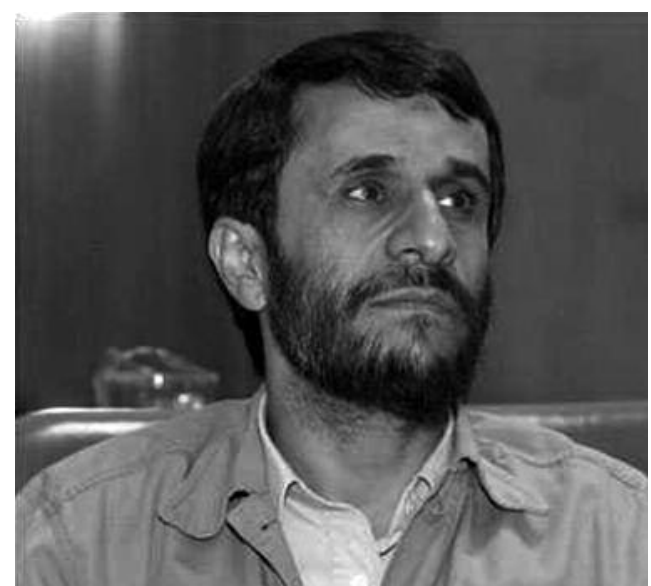

Fascist? Mahmud Ahmadinejad, Irans nye president.

revolusjonen med dens spektakulære omfang var en ganske fredelig revolusjon helt til de to siste dagene før maktovertakelsen. Selv Khomeini ble av radikale krefter anklaget for å være for kompromissvillig, siden han nektet å gi en fatwa om et militært oppgjør med sjahens regime.

Det postrevolusjonære regimet var under press fra radikale politiske krefter, blant annet Mujahedin og Fadaian Khalg og det kommunistiske Tudeh-partiet, som krevde det som ble kalt "revolusjonær straff" (mojazat-e enghelabi) eller revolusjonær henrettelse (e' dam enghelabi) av viktige militære og politiske aktører i det gamle regimet. Da Mehdi Bazargan, den første postrevolusjonære statsministeren, snakket om tilgivelse og rettferdige retts- prosesser for sjahens menn, ble han anklaget for å være liberal og ikke-revolusjonæ, kompromissvillig eller rett og slett anti-revolusjonær.

Mehdi Bazargan og hans liberale regjering var en minoritet $i$ datidens politiske klima. Vold var essensen av revolusjonære handlinger på den tiden. Men det tok ikke lang tid før alle andre revolusjonære fraksjoner selv fikk smake denne essensen og ble eliminert av islamister under ayatolla Khomeinis lederskap. Inntil Khomeinis død var alle hans tilhengere enstemmig enige om at den politiske opposisjonen som hadde til hensikt å styrte den islamske staten fortjente å knuses brutalt.

Etter Khomeinis død og etter framveksten av postislamismen har imidlertid vold blitt problematisert i en skala som aldri før. Med Khatamis presidentskap ble fred og toleranse (tasamoh og tasahol) den viktigste delen av den politiske diskursen i landet. Khatamis anti-vold-kampanje ble utfordret i og med flere drap på intellektuelle og politiske aktivister vinteren I999, det brutale oppgiøret med studentopprøret sommeren samme år og attentatet mot Said Hajarian, Khatamis fremste rådgiver, vinteren 2000. Det siste ble oppmuntret av konservative krefter og rettferdiggjort av ayatolla Mesbah Yazdi. Han er den eneste av de kjente religiøse lærde som ga sin støtte til Mahmud Ahmadinejad, Irans nye president.

\section{En debatt om vold og dens grenser}

Vold var det viktigste politiske temaet i Iran sommeren I999. Det var særlig to spørsmål som kom i fokus: Hvem har rett til å bruk vold, og i hvilket omfang? Khatami, som ønsket å giøre den islamske staten til en virkelig rettsstat, argumenterte for at det var staten og bare staten som kunne benytte seg av vold, og med begrenset omfang. I de første to årene av sitt presidentskap prøvde Khatami å virkeliggiøre dette målet, men han møtte motstand fra de konservative. Hezbollah-grupper plaget studenter, angrep politikere og politiske møter, og truet med brutale aksjoner mot reformvennlige krefter. Så lenge volden ble utført av Hezbollah-grupper som ingen 
støttet åpent, kunne Khatami legge skylden på ytterliggående grupper som ikke respekterte loven. Han så Ansar-e Hezbollah som en gruppe naive ungdommer med gode intensjoner som begikk ulovlige handlinger.

Men da Mohammad Taghi Mesbah Yazdi ga sin støtte til Ansar-e Hezbollahs handlinger og spurte om ikke Khatamis toleransediskurs var ikke-islamsk ble Khatami avvæpnet. Ifølge Mesbah Yazdi må en muslim ikke nøle med å bruke vold når det er i islams interesse. Åredusere islam til en liberal ideologi om toleranse er vold mot islam, mener han.

Mens Khatami og hans tilhengere rettferdiggjorde vold mot opposisjonen på 8otallet som selvforsvar og legitimt fordi motstanderne brukte våpen mot det islamske regimet, så Mesbah Yazdi på vold som forebyggende angrep mot politiske og ideologiske motstandere. Slike angrep kan utføres ikke bare av staten, men av enhver muslim som oppdager farer mot islam og den islamske staten, hevdet han. Mesbah Yazdis løsning var klar og tydelig: Tilintetgjør de som skaper problemer for den islamske staten og de som setter spørsmålstegn ved islams rolle i den iranske staten.

\section{To oppfatninger om vold}

Khatamis reaksjon var voldsom. Han kalte Mesbah Yazdi for en reaksjonær voldsteoretiker, selvfølgelig uten å nevne navnet hans eksplisitt. Mesbah Yazdi prøvde å presentere Khatami og reformvennlige krefter som liberalpasifister. Selvsagt var ikke Khatami eller andre reformvennlige politikere og politiske aktivister pasifister. Det de krevde var at staten var den eneste institusjon som kunne ha monopol på voldelige midler, og at den skulle være kontrollert av demokratiske organer og det sivile samfunn.

Khatami visste veldig godt at Ansar-e Hezbollah var organisert med Irans høyeste leder Ali Khameneis samtykke, og at de rekrutterte sine medlemmer fra Basij-

\section{Ahmadinejad vil gjenreise Iran som et islamistisk og revolusjonoert land slik det var på 8o-tallet.}

militsen, men i begynnelsen trodde han at disse gruppene ville bøye seg for lover og demokratiske spilleregler til sist. Tross all støtte som de paramilitære Hezbollah-gruppene hadde fått, hadde de begrenset myndighet til bruk av vold. Mer brutalt arbeid ble utført av Ministeriet for etterretning og sikkerhet, som sporet "politiske og kulturelle konspirasjoner" mot den islamske staten, lokaliserte mulige konspiratorer og truet dem på livet eller eliminerte dem uten rettssak. Khatami måtte altså kjempe mot både illegale og legale organisasjoner som truet legale politiske og kulturelle aktiviteter. Mens Khatami så det som sin oppgave å forsvare konstitusjonen ved å gjøre slutt på statens bruk av eller støtte til ulovlige voldshandlinger, arbeidet Mesbah Yazdi for å forsvarere slike handlinger.

\section{Mesbah Yazdi: Anasro bero' b}

Ifølge mange kilder kan ikke ayatolla Mesbah Yazdi vise til nevneverdig radikal politisk aktivitet i sin førrevolusjonære karriere. Mange veteraner hevder til og med at Mesbah Yazdi tok avstand fra radikal politikk mot sjahen. Han blir også beskyldt for ikke å ha støttet krigen mot Irak (I980-88). Det 
sies at han nektet sine elever å delta i krigen. Det ville være underlig om en slik figur hadde stått Khomeini nær. Dersom Khomeini hadde hatt tiltro til Mesbah Yazdi ville han gitt ham et viktig embete, noe Khomeini aldri gjorde.

Ifølge reformvennlige krefter prøvde Mesbah Yazdi å redefinere den islamske staten, slik at dens legitimitet ikke var basert på folkets vilje, men på det han betraktet som islamske sannheter. Dette er grunnlaget for at Mesbah Yazdi mener staten kan bruke ubegrenset vold for å opprettholde seg selv. For Mesbah Yazdi er ikke den islamske statens grunnprinsipper og dens praksis slik den er konkretisert i islamske lover tema for diskusjon. Han avviser ikke verdien av diskusjon for å overbevise motstandere av en islamsk stat, men han mener at slik diskusjon ikke er tillatt når som helst. Ifølge Mesbah Yazdi var det nødvendig å overbevise ved å argumentere så lenge folket ikke var villige til å støtte en islamsk stat, men etter at den islamske staten har blitt dannet er det en stor synd å være mot den. Mesbah Yazdis politiske teori ble beskrevet som anasro bero' b. I politisk sammenheng kan begrepet forstås på to måter. For det første kan det bety å tvinge folk $i$ et samfunn mot målet lederne har planlagt gjennom vold, dersom folket ikke kan overbevises på fredelig vis. Men det kan også bety å seire over politiske rivaler gjennom vold.

Ifølge Mesbah Yazdi fikk ideen om den islamske staten gjennomslag hos et flertall av folket gjennom fredelig argumentasjon. Men så snart den islamske staten var etablert for å virkeliggjøre sannhet og rettferdighet, mener Yazdi at det var riktig av Khomeini å benytte seg av vold mot vestliginfluerte politikere og intellektuelle som

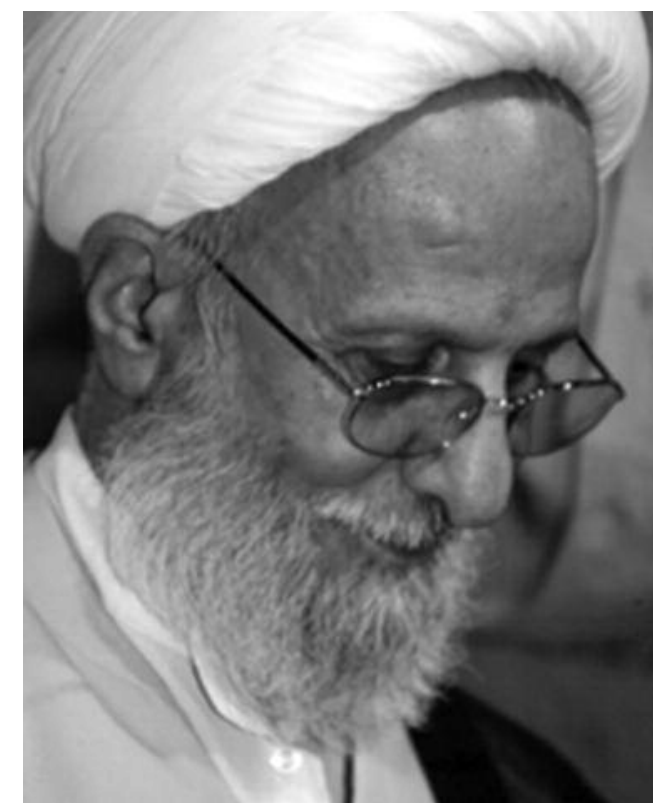

Forsvarer vold: Mesbah Yazdi.

truet den islamske staten og dens grunnleggende verdier. ${ }^{3}$ Det betyr at for Mesbah Yazdi har den islamske ideologien krav på et fredelig klima for å overvinne den rådende ideologien i et samfunn, men han lar ikke rivaliserende ideologier få den samme retten under islamsk styre. Ifølge ham må ethvert ideologisk angrep på den islamske staten oppfattes som en krig mot islam. Videre trenger ikke den islamske staten å legitimere seg overfor folket gjennom valg. Mesbah Yazdis voldsorienterte utspill fant sted i en tid da de konservative var i klart mindretall, men hans engasjement ble lovpriset av den yngre og mer radikale generasjonen av konservative.

\section{Vold og forskjellige tolkninger}

Debatten om forholdet mellom islam og folkets demokratiske rettigheter på den ene siden, og diktatoriske og autoritære midler på den andre, resulterte i en annen debatt: om det finnes forskjellige tolkninger av 
islam eller ikke. En debatt som ble startet av Abdolkarim Soroush og hadde preget intellektuelle islamistmiljøer ti år tidligere gikk nå $\mathrm{i}$ full offentlighet $\mathrm{i}$ aviser, fredagsbønner og på TV. Khatami og reformvennlige hevdet at man kan diskutere hvorvidt islam er en tolerant eller voldelig religion, men at folk som oppmuntrer til voldshandlinger uansett må stå til ansvar. Mesbah Yazdi svarte med å anklage dem som mener at det finnes forskjellige tolkninger av islam og at disse tolkningene har samme rett til å utrykke seg i offentlighet for å utøve vold mot islam og å forråde den islamske staten. Ifølge Mesbah Yazdi finnes det bare én sann tolkning av islam. Alle andre tolkninger er falske konspirasjoner mot islam og må bekjempes med vold. Khatamis reaksjon var kategorisk:

"De som teoretiserer volden har skylden [..] Oppmuntring til vold strider mot den lovlige orden. Du kan ikke gi ordre om voldsbruk $i$ religionens navn fordi du mener at din religion har gått tapt. Tror du kanskje dine illusjoner er [den sanne] religion? Du kan si det du vil. Ingen hindrer deg $i$ å si det du har lyst til å si. Men å hevde at illusjoner og innbilninger er identisk med religion er å utnytte troende folk for å true den orden som er opprettholdt av den islamske staten, og kalles opprør mot denne staten."

Khatami oppfattet Mesbah Yazdis begeistring for vold som en del av en større konspirasjon mot sin regjering. Han anså voldsorienterte ideer i islams navn som en taktikk for å skape et ustabilt politisk klima og sosialt anarki, noe som ville rettferdiggiøre å trekke militære krefter inn i politikken. Reaksjonene blant religiøse ledere i byen Qom var splittet. Reformvennlige marja' er som ayatolla Montazeri, ayatolla Sanei og innflytelsesrike religiøse ledere som ayatolla Taheri fordømte Mesbah Yazdis rettferdiggiøring av vold i islam og $i$

\section{Ifølge Mesbah Yazdi må en muslim} ikke nole med å bruke vold når det er $i$ islams interesse.

den islamske staten. ${ }^{5}$ Konservative marja' er som ayatolla Amoli, Nuri-Hamedani og Makarem Shirazi ga støtte til Mesbah Yazdis synspunkter. De anklaget de reformvennliges diskurs om en tolerant islam som en fare for implementeringen av islamske lover som ville sette islams integritet i fare. De advarte reformvennlige krefter om at hvis de var bekymret for lov og orden i samfunnet kunne de ikke tillate kritiske holdninger mot islams prinsipper. ${ }^{6}$ Var det religiøse overbevisninger som bestemte synet på vold i denne sammenhengen, eller var det politiske orienteringer som avgjorde hvem som inntok de to posisjonene? Mens konservative religiøse ledere hadde trukket islamske lover inn i debatten, var de reformvennlige religiøse lederne stille om denne saken fordi de fortsatt strevet med å finne en løsning på det paradoksale forholdet mellom deres demokratiske og egalitære reformprogram og islamske lover som avviste slike demokratiske og egalitære rettigheter. Men denne debatten om vold i islam motiverte noen av de fremste skriftlærde, som Montazeri og Sanei, til å presentere sine reviderte syn på islamske lover i samsvar med 
menneskerettighetserklæringen. ${ }^{7}$

\section{Frykt for politisk vold paralyserte reformer} Khatami, som presenterte demokrati og toleranse som motstykket til diktatorisk politikk og vold, hadde en konstant frykt for voldelige oppgjør mellom ytterliggående krefter i den konservative og den reformvennlige leiren. Rett etter studentopprøret i I999 advarte 24 ledere for Revolusjonsgarden og Basij-militsen om at dersom Khatami ikke hadde makt til å kontrollere radikale reformister ville de bruke alle

\section{Prisen de reformvennlige måtte} betale for å hindre vold var å ikke få gjennom sitt program.

midler for å gjøre denne jobben. ${ }^{8}$ Sannsynligvis inngikk Khatami et kompromiss med radikale konservative om ikke å støtte radikale studenter. Det han fikk i retur var garantier fra Revolusjonsgarden og Basij om at håndteringen av studentopprøret ikke ville resultere i blodbad. Spørsmålet om de konservative var i stand til å utføre ubegrenset bruk av vold mot studenter ble ikke avklart. En slik voldelig reaksjon kunne resultere i bredere og voldeligere reaksjoner fra folket og fordømmelse fra internasjonal presse. Reformvennlige politikere sier gjerne at de reddet landet fra vold ved å inngå et kompromiss med de konservative, selv om det skadet deres politiske rykte blant folket. Det finnes mange episoder som underbygger denne påstanden. Blant de viktigste kan nevnes dødsdommen mot Ahmad Batebi som ble arrestert i studentopprøret i I999, dødsdommen mot redaktøren av en studentavis som ble anklaget for å ha fornærmet den tolvte imam, dødsdommen mot Hassan Yusefi Eshkevari for ha sagt at hijab ikke er en nødvendighet i islam, og til sist dødsdommen mot Hashem Aghajari for hans kritikk av taghlid-tradisjonen i shia-islam. ${ }^{9}$ Ved alle disse episodene hindret Khatamis forhandlinger at dødsstraffen ble utført, og hver gang måtte Khatami forhandle med en del av sitt politiske program. Gjennom denne prosessen vokste det frem en radikal fraksjon, med støtte fra Vokterrådet, Revolusjonsgarden, Basij-militsen og en innflytelsesrik fraksjon i rettsystemet dominert av Mesbah Yazdis tidligere elever som skulle bli den sterkeste fraksjonen innenfor den konservative leiren.

Det var denne fraksjonen som vant byrådsvalget i 2003, parlamentsvalget i 2004 og presidentskapet i 2005. Aktørene i denne fraksjonen har blitt fremstilt som de mest voldelige kreftene i Iran, og noen av dem er medlemmer av Ahmadinejads regjering. Prisen de reformvennlige måtte betale for å hindre vold var at de ikke fikk gjennomført sitt reformprogram. Ifølge reformpolitikeren Mustafa Tajzadeh, tidligere vise-innenriksminister i Khatamis regjering, oppfatter ikke de reformvennlige valgnederlagene og tapet av den brede folkelige støtten som et politisk nederlag. Et virkelig nederlag for de reformvennlige, ifølge Tajzadeh, ville ha vært utbrudd av vold under president Khatami. ${ }^{\text {Io }}$

\section{Har voldsdiskursen vunnet?}

Den nyvalgte presidenten Mahmud Ahmadinejad lovpriser Mesbah Yazdi som sin læremester. Hans minister for etterretning og sikkerhet og hans innenriksminis- 


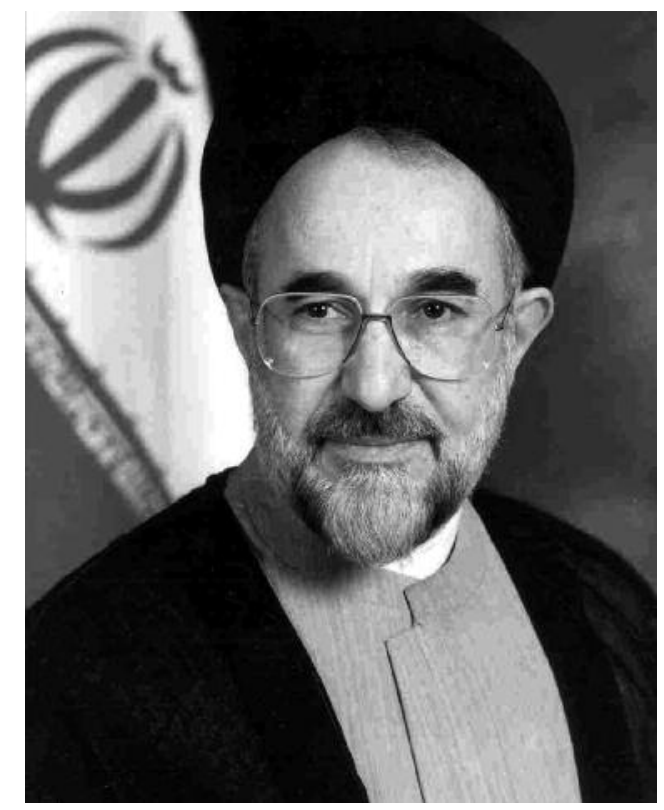

Fryktet vold: Mohammad Khatami, Irans forrige president.

ter er tidligere elever av Mesbah Yazdi. Sistnevnte er sammen med sine elever anklaget for å stå bak drap på intellektuelle og politiske aktivister i I999 og mange andre politiske drap i Rafsanjanis presidentperiode (I989-I997). Voldsteoretikere og voldsutøvere dominerer dermed hele den islamske staten. De har større tilgang til medier for å spre sin voldsideologi og større muligheter for å utføre voldelige aksjoner. Men det er én ting vi må huske her: Grunnen til at flertallet av iranere ga sine stemmer til Ahmadinejad var at han lovet å kjempe mot økonomisk korrupsjon, innføre en rettferdig deling av landets rikdom og skape arbeid.. Det var ikke så mange som stemte for Ahmadinejad på grunn av hva Mesbah Yazdi mener om forholdet mellom islam og vold. Det vil bli vanskelig for Ahmadinejads regjering å tilfredsstille både sin læremester og folket særlig fordi læremesteren er en del av den økonomiske korrupsjonen han har lovet å bekjempe. ${ }^{\text {II }}$ Korrupsjonsproblemet splitter voldsideologer og voldsutøvere innenfor den neokonservative fraksjonen.

Teheran-avdelingen av Ansar-e Hezbollah offentliggjorde i sommer en erklæring som bekymret mange i den neokonservative leiren. Ansar-e Hezbollah hevdet i denne erklæringen at organisasjonen har lokalisert alle regimemotstandere under Khatamis presidentperiode og vil tilintetgjøre dem i den nære fremtid. ${ }^{\text {I2 }}$ Erklæringen ble kritisert fra noen av grunnleggerne av Ansar-e Hezbollah. De anklaget forfatterne av erklæringen for å være anarkister og fordømte deres intensjoner og mulige planer som ulovlige. To ledere som sto bak angrep mot reformorienterte intellektuelle og politikere, Massud Dehnamaki og Hussein Alahkaram, fordømte erklæringen. Abas Salimi-Namin, tidligere reaktør av Teheran Times og en ledende neokonservativ figur, anklaget gruppen for å motarbeide Ahmadinejads forsøk på å realisere sine politiske program, som er økonomisk rettferdighet og kamp mot korrupsjonen. ${ }^{13}$

En åpen debatt mellom Abas SalimiNamin og en av Ansar-e Hezbollahs ledere, Sadegh Ashktalkh, viser hvor utslitt det ideologiske belegget for politisk motivert vold har blitt. Ifølge Abas Salimi-Namin er Ansar-e Hezbollahs siste erklæring en konspirasjon mot den nye presidenten. Hensikten skulle være å fremstille Ahmadinejads politikk som voldelig og intolerant. Salimi-Namin mener de reformvennlige prøver å tegne et voldelig og intolerant bilde av den nye presidenten for å kunne gripe makten igjen, og at Ansar-e Hezbollah bidrar til å realisere et slikt politisk mål. ${ }^{\mathrm{I}}$ En annen viktig sak som ble avslørt i denne debatten var at en av lederne av Ansar-e Hezbollah ikke var en dedikert og 
ydmyk aktivist fra Basiji-militsen, men en teknokrat og sjef for Irans oljeselskap. ${ }^{15}$ Det faktum at de som oppmuntrer til vold for å forsvare islams prinsipper er så ressurssterke kan være en kilde til bekymring. Men ideologer som vil forsvare islam gjennom vold samtidig som de er en del av den økonomiske korrupsjonen vil bli avslørt og kontrollert på samme tid.

Hezbollah har vært en av de viktigste kildene til vold i Iran de siste ti årene, og spilte en avgjørende rolle for Khatamis nederlag. Nå er imidlertid disse gruppene blitt et problem og må kontrolleres. Men disse gruppene kan ikke kontrolleres uten videre; deres ledere må overbevises om at deres handlinger kan sette den konservative leiren i fare. De skal overbevises om at deres voldelige handlinger svekker den nye regjeringen og parlamentet. Hezbollahgrupper må overbevises om at deres bekymringer vil tas til følge gjennom legale kanaler.

Hvis de neokonservative makter å kontrollere Hezbollah-grupper og etablere staten som en institusjon med et effektivt monopol over bruk av vold, har de klart en oppgave som Khatami ikke klarte å gjennomføre.

Ahmadinejad har vært en radikal islamist som ikke har nølt med å bruke vold av ideologiske grunner, men det han lovet som presidentkandidat var ikke forvar av islamske verdier og åndelig frelse. Løftet hans var å forbedre folks levekår, og folket krever det han har lovet. Folkets krav kan fungere som en modererende faktor som kan endre radikale islamister til pragmatiske politikere. Ifølge Tajzadeh har Ahmadinejad forandret sitt slagord fra Yom al-fasl (dommedagstid) til Yom al-rahm (omsorgstid), hvilket illustrerer hvor dypt reformideologien har påvirket ham. ${ }^{\mathrm{I}}$

Spørsmålet som gjenstår er hvorvidt voldsideologien formulert ved folk som Mesbah Yazdi og voldshandlinger gjennomført av Hezbollah-grupper har vært uttrykk for en genuin politisk og ideologisk bevegelse, eller bare en fase $i$ en politisk strategi som har søkt å fremstille Khatami

\section{m \\ Voldsteoretikere og voldsutøvere dominerer hele den islamske staten.}

og hans medarbeidere som maktesløse politikere som verken er i stand til å skape demokrati eller opprettholde ro og orden i samfunnet. De neokonservative klarte å oppnå sine politiske mål, men klarer de å holde sammen på grunnlag av en felles ideologi? Splittelsen innenfor den neokonservative leiren etter valget av Ahmadinejad indikerer at det ikke finnes et slikt felles ideologisk grunnlag. Denne splittelsen indikerer at de neokonservative ikke har hengitt seg til en ensrettet voldsorientert ideologi for å skape et mer islamistisk samfunn, slik 8o-tallets islamister gjorde. Derfor har den islamismen som de neokonservative og Mesbah Yazdi representerer vist seg å være en utslitt islamisme uten substans, ideologisk overbevisningskraft eller politisk mobiliseringskraft. Det betyr at anasro bero' $b$ var en politisk strategi for å oppnå politisk makt gjennom frykt. ${ }^{17}$

\section{Konklusjon}

Da Mehdi Bazargan og hans regjering ville kontrollere revolusjonær vold var Mohammad Khatami og andre revolusjonære på et stadium hvor de uansett ideologisk overbevisning og politisk orientering nærmest 
anså voldsbruk som en dyd. Men tidene har forandret seg. I motsetning til på i96oog 70-tallet har det ikke oppstått en eneste politisk organisasjon i Iran som oppmuntrer til væpnet kamp siden begynnelsen av I980-tallet. Mujahedin Khalgh, som fortsatt tror på væpnet kamp, er blitt redusert til en isolert sekt uten folkestøtte. Dagens politiske opposisjon oppfatter politisk motivert vold som barbarisme uansett hvem som utfører den, staten eller opposisjonen. Betyr dette at iranere har blitt mer humane enn de var i revolusjonens tid, eller at de har mer respekt for menneskeverdet enn før? Slike spørsmål vil jeg overlate til vulgærhistorikere og essensialister å stille. Vold er en del av menneskets natur. Men iranere er i ferd med å forlate politisk vold i sin helhet fordi de har klart å danne, som Nietzsche $\mathrm{sa}^{\mathrm{r}}{ }^{\mathrm{8}}$ deres eget minne om vold gjennom sår de bærer med seg fra krig og politisk vold i deres nære fortid.

$$
\text { - } f \text { • }
$$

I Shargh, o8.08.2005.I kjølvannet av av Rafsanjanis økonomiske reformer på begynnelsen av 1990-tallet dannet en gruppe krigsveteraner organisasjonen Ansar-e Hezbollah for å bevare revolusjonens verdier mot det som ble kalt vestlig kulturell agresjon. Ifølge Ansar-e Hezbollah prøvde Vesten å infiltrere landet gjennom kulturelle kanaler fordi det ikke klarte å knuse den islamske revolusjonen politisk og militær. Derfor plaget de kvinner som ikke brukte hijab fullstendig, angrep bokhandlere som solgte "anti-revolusjonæ" litteratur og intellektuelle som ble identifisert som agenter for vestlig kultur. Mange av Ansar-e Hezbollahs medlemmer kom fra Basijmilitsen, en organisasjon som ble dannet i begynnelsen av krigen mot Irak på 8o-tallet. Militsen rekrutterte frivillige til fronten, vanligvis unge menn, men også eldre. Basij-militsen spilte en avgjørende rolle i krigen. Mohammad Ali Zakariaiy (red.): "Mesbah Yazdis

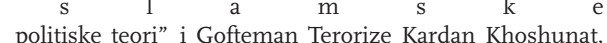
Teheran I999, s. 27-29.

4 Iran (dagsavis) 22.08.I999.

5 Neshat (dagsavis) o8.08.I999, men ayatolla Sanei fordømte terror og vold mot politisk og ideologiske motstandere få måneder tidligere i sammenheng med drap

$\mathrm{p}$

intellektuelle vinteren ' 99 .

6 Resalat (dagsavis) 08.09.I999 og 09.09.1999.

7 Ayatolla Montazeris Resaleh-e Hoqoq, Entesharat-e Saraiy 2004 Teheran, og Saneis interviu med Chicago Tribune 08.06.2005, og intervju med Kristian Fobiani (italiensk fjernsyn) 05.05 .2005 .

8 Hamshahri 21.07.I999.

9 Taghlid vil si at man velger seg en skriftlærd som sin veileder i religiøse spørsmål, og tar til følge de meningene denne skriftlærde har om enhver sak. Slik dannes en pyramide med noen få svært innflytelsesrike skriftlærde på toppen. En slik autoritetsperson kalles marja taghlid.

IO Rooznet, 24.08.2005

II http://www.entekhab.ir, 24.08.2005.

I2 Shargh, 2I.08.2005.

I3 Ibid.

I4 Ibid.

I5 Ibid. En av lederne av Hezbollah-gruppen er Massoud Soltanpour, managing director of Iranian Offshore Engineering and Construction Company (IOEC).

I6 Rooznet 24.08.2005.

I7 Iranian Labour News Agency I8.I0.1983.

I8 Friedrich Nietzsche: «On The Genealogy of Morals», translated by Walter Kaufmann and R.J. Hollingdale, New York: Vintage Books, I989, s. 6r. 